\title{
The Grave as a Doorway to the Other World: Architectural Religious Symbolism in Iron Age Graves in Scandinavia
}

\author{
ANDREAS NORDBERG \\ Stockholm University
}

\begin{abstract}
During the last twenty years, the category 'grave' has been the subject of increasing debate in Swedish archaeology. It has been recognized that monuments commonly regarded as graves are sometimes also found in cultic contexts other than those associated with death and burial. In many cases, for instance, monuments similar to graves have been erected at cult sites, and seem to have been used in sacrificial practices rather than for burials. According to archeological, textual and onomastic sources, it was common practice in Old Norse religion to suspend sacrificial victims from trees or from upraised posts, or to deposit offerings at the base of sacred rocks and boulders. In all these cases, the trees, posts and boulders seem to be representations of the World Axis, depicted in cosmological myths as a Cosmic Tree, Pillar or Mountain. I argue that these various representations of the World Axis are also incorporated in the architectonic symbolism of several forms of grave monuments in pre-Christian Scandinavia. The architectonic shape of these monuments could thus be used in several different contexts, since they represented a 'Cosmic Center' and a 'doorway' to the Other World.
\end{abstract}

Keywords: grave, burial, cult site, architectonic symbolism, World Axis, Cosmic Center

Death is a cosmic drama, altering human existence in the most dramatic ways. When death occurs, the deceased is thought to leave the world of the living, and after a liminal period to be united with the ancestors in the Other World. The passage between the cosmic worlds is often regarded as a difficult and dangerous journey; for this reason, in many cultures the dead are aided on the path by certain ritual activities performed by the living before, during and after the funeral ceremony. These activities can take many forms, including laments, food given to the dead, sacrifices to 
the god of death, or ritual dramas performed in context of the funeral. ${ }^{1}$ In Old Norse burial customs, for example, cultic dramas were apparently performed containing certain mythical motifs, with the dead traveling to the Other World on horseback or in horse-drawn carts, guided by psychopomps in the shape of one or two dogs who knew the roads to the Nether World. These dramas involved the use of real animals; in the final act, the animals were slaughtered and buried with the dead. (Nordberg 2004, 241-55.)

As many of these rituals took place at the time and place of the funeral, the grave monument can be regarded as a passage or threshold, i.e. a 'gateway' between this and the Other World. For this reason, in Old Norse poetry scalds sometimes used euphemisms such as daudra dura 'doors of the dead' (Gróagaldr st. 1, Edda 1927, 298), or Heljar grindr 'the gates of the Kingdom of death' (Gylfaginning ch. 49, Snorri's Edda 1988, 47), in referring to the grave. In the scaldic poem Sonatorrek (st. 3, Skj. B1, 34) dated to about 960 CE, Egill Skallagrímsson named his father's grave-mound naustdýrr, 'the door of the boathouse'. In this compound, both naust 'boathouse' and dýrr 'door' probably reflect some essential conceptions of the journey to the Other World, as the dead were frequently buried in ships (or rather, in most cases actually cremated lying in one) (Nordberg 2004, 273-4). There are also examples of door-shaped constructions built into the brim of or in close connection to graves. In an account of the burial of a chief among the rus $^{2}$ in the year $922 \mathrm{CE}$, the Arab writer Ibn Fadlan describes a wooden door-post erected in front of the ship in which the dead chief was to be cremated. A young female slave, who was to accompany the chief in the afterlife, was lifted up in front of the door-post; and as she looked over it, she shouted that she could see her master in the Other World (Ibn Fadlan, cf. Wikander 1978, 67-8). Since the body of her deceased master had already been placed in the burial ship, we can assume that when she declared she beheld the Kingdom of death, the slave woman was in fact looking into the ship inside the still open grave (Nordberg 2004, 80). Traces of door-posts in connection with graves are also attested in archaeological excavations (Arrhenius 1970), and a certain kind of box-shaped stone construction, referred to in Swedish as the sydvästport ('southwest gate') is usually also thought

1 Here I follow van Gennep's and Turner's comprehensive studies on the subject (van Gennep 1960; Turner 1969; 1970), although I do not give further references to their work in the text.

2 The rus was a multi-ethnical group of people in western Russia, which for the main part seems to have been of eastern Swedish origin - compare the Central Swedish coastal area Roslagen, and the Finnish word Ruotsi 'Sweden'. 
to have had similar functions (Gräslund 1969). Furthermore, during the period from about the sixth century to the end of the Viking Age, graves are sometimes encircled by small ditches (Swe. sing. kantränna). In many cases part of the ditch, in the south to south-west area, is not dug, so that the grave is not completely enclosed. This should probably be regarded as an 'opening' or 'bridge', leading inside to the actual grave area (Lögdqvist 2009, 50-1, 53-4).

From a mythic perspective, the grave monument was the 'gateway' the dead had to enter to start the journey to the Land of the Dead. But this significance was not limited to the duration of the funeral; the grave also seems to have served as a 'door' to the Other World for example on occasions when surviving relatives were trying to summon the dead to the world of the living. For example in the poem Hervararkviða (Tolkien 1997, 11-23), Hervor, the daughter of Heiðrekr, is summoning her father from his grave. As she performs the necromancy, suddenly (Tolkien 1997, 17, my translation):

Hnigin er helgrind, haugar opnast.
The Gate of the World of Death is lowered, grave mounds open

Hervor accomplishes her objective. When she returns, she finds herself heima $i$ millum 'between the worlds', while fires from the nether world blaze all around her.

Hervararkviða is preserved in the fornaldarsaga Hervarar saga ok Heiðreks from the thirteenth century, but the poem was probably composed in the twelfth century (Simek \& Pálsson 1987, 164-6) based upon an older heroic legend.

Conceptions of necromancy continued well into the Christian Middle Ages. In some written accounts from the thirteenth century and onwards, as well as in later folklore, the dead are conjured up from the Underworld to provide advice, knowledge of the future, and other support to the living (cf. Ellis 1943, 151-69). According to some medieval Scandinavian provincial laws, summoning the dead is to be regarded as heathen practice; it is therefore prohibited according to Christian Law. For instance in the $\mathrm{Gu}$ lapings Christenret (v, ii; NGL 1846, 308), preserved in manuscripts from the beginning of the thirteenth century, it is prohibited to fræista draugha upp at væikia æda haugbua 'awaken dead corpses and those who dwell in (grave-) mounds'. Equivalent practices are still found as late as the beginning of the eighteenth century, as attested in Swedish reports of legal proceedings. An old woman in the Swedish province of Gotland, for example, is said to 
have cured diseases by reciting an old charm, beginning as follows (Wall $1989,76,92)$

Syster gå til grafwen, Sister goes to the grave,

ok wecker up käre brodren sin. awakening her beloved brother.

Exactly how these necromantic practices were carried out in pre-Christian times is not known, but some indications are found in the Old Norse sources. In the late mythological poem Baldrs draumar we are told that Óðinn's son Baldr suffered from bad dreams. This worried the gods, who met for council. In the process, they came to the conclusion that the dead had to be consulted. Óðinn then mounted his eight-legged horse Sleipnir, who could traverse the boundaries of the Cosmic Worlds, and rode down to Hel, the nether kingdom of Death. When he reached a grave mound located just outside the Gates of $\mathrm{Hel}$, he dismounted. The grave belonged to a volva, a seeress, whom Óðinn conjured up and started to question, beginning with the following words (Edda 1983, 278, my translation):

segðu mér ór helio -

ec man ór heimi.
Tell me from Hel,

I ask you from the world of men.

Baldrs draumar highlights the grave's function as a link between this and the Other World in an Old Norse context. Óðinn is said to conjure up the volva from her grave-mound. According to the poem, the mound is situated just outside the gates of Hel. Still, it is probable that the poem's audience would draw associations between the volva's mound and the earthly grave fields - that they recognized, so to say, of some kind of metaphysical connection between the World of the Dead and the grave fields in this one. This association is further emphasized when, according to the poem, Óðinn asks his questions from the World of the Living, and the volva gives her answers from the World of the Dead. Óðinn is able to do this because the grave offers a link between this world and the next (cf. Nordberg 2004, 73-80).

\section{Cult Site, World Axis and Cosmic Center}

A place providing an opening to the Other World is usually called a 'cosmic center'. Based to a large extent on motifs and conceptions collected and studied by Uno Holmberg (later Harva) (1922), the concept was first introduced by Mircea Eliade (1959); while a number of Eliade's conclusions have been 
questioned in recent debates, the concept of the cosmic center is still useful in this context. The term suggests that certain spatial locations, at certain moments in time, may be perceived as offering a conjunction of the cosmic worlds. The cosmic center usually contains something that represents an axis mundi, a 'world axis', uniting the cosmic worlds. In cosmological myths, the world axis has a twofold function: it supports the sky from falling, while at the same time it provides a uniting link, along which gods, culture heroes, shamans and the dead can travel between the cosmic regions. In myth, the world axis can take many forms, but it commonly occurs in the shape of the trunk of a Cosmic Tree, a Cosmic Pillar or a Cosmic Mountain (cf. Holmberg 1917; 1922; Edsman 1944; Hultkrantz 1996). Old Norse religion offers examples of all three variations. Since these mythologemes have been the subject of several thorough and comprehensive studies in recent years, here I give merely a brief outline of the mythic motifs and their ritual equivalents (cf. Meletinskij 1973a-b; Bauschatz 1982; Drobin 1991; Drobin \& Keinänen 2001; Nordberg 2004, 159-68; Andrén 2004; Sundqvist 2004).

Several Old Norse myths relate about the Cosmic Tree, known under names such as Yggdrasill, Læraðr and Mímameiðr. In the eddic poems Voluspá and Grimnismál (Edda 1983), which probably in its most parts can be dated to the end of the tenth or beginning of the eleventh century, as well as in Gylfaginning (ch. 15-16) in Snorri's Edda (1988, 17-19) from the beginning of the thirteenth century, Yggdrasill is said to be an ever-green ash-tree, standing over a cosmic well. ${ }^{3}$ It has three roots, stretching over the whole world: Man lives beneath one root, giants beneath another and the dead beneath the third. An eagle sits on the tree's top, and the dragon Niðhǫggr, along with several snakes, gnaw at its roots. A squirrel Ratatoskr runs up and down the trunk and shouts abuse at the eagle and the dragon. Four stags, or in a different version a stag and a goat, live in the tree's branches and graze on the leaves. Under the tree the gods gather in council. In Rúnatals páttr, a passage in the compiled poem Hávamál, Óðinn sacrifices himself to himself by stabbing himself with a spear and hanging himself by the neck in the Cosmic Tree (Edda 1983, 40-1). Óðinn hanging in the tree is said to 'ride the gallows'; this explains the name Yggdrasill, meaning 'Ygg's, ie. Óđinn's horse'. Several scholars have suggested that this drama performed by Óðinn should be regarded as the mythological prototype of an initiation

3 This well is in various versions called Urðarbrunnr, Mímis brunnr and Hvergelmir. According to some sources these names refer to three different wells, but most scholars agree that the three names most probably are different epithets for the same spring - the Well of fate that contains the liquid of life, underneath the roots of the Cosmic Tree. 
rite or human sacrifice (de Vries 1934; Ström 1947; Schjødt 1993; Drobin 1991, 108-10; Sundqvist 2004, 147-54).

At cult sites, the concept of the Cosmic Tree seems to have been represented by actual sacrificial trees. In the written records of religious practices in the centuries preceding the Christianization of Scandinavia, there are a number of accounts of sacrifices in which animals, parts of animals (mostly heads and extremities) and even humans were suspended in sacrificial trees (Hultgård 1993). One of the most interesting of these depictions is given in the account by Adam of Bremen of the cult site at (Old) Uppsala (Figure 1), in the province of Uppland, Sweden, written during the years 1073-1075. Adam's description of the cult site is strangely similar to the mythic images of the Cosmic Tree and the Cosmic Well (Adam, book IV, 26-27, scolion 138). Some scholars have proposed that Adam used mythological motifs in depicting the cult site (Alkarp 1997). It is more reasonable, however, to assume that the cultic well and tree were commonly depicted with these 'mythic' motifs and notions, as passages from cosmological myths regarding the cosmic well and tree were recited in ritual practice (Drobin 1991, 107). Sacrificial trees are also confirmed by archaeological evidence. For instance, beneath the floor in the church at Frösön (the toponym means 'island of the god Freyr'), in the province of Jämtland in Sweden, a large quantity of animal bones was found scattered around a rotten birch stump. These are most probably the remains of animal sacrifices suspended in the sacrificial tree, at the cult site that preceded the Christian church. The remains have been dated to 900-1050 CE (Iregren 1989).

As a mythological phenomenon, the Cosmic Tree has its parallel in the Cosmic Pillar. This motif is widely distributed over the northern hemisphere as well as in early civilizations. In an Old Norse context (cf. Drobin \& Keinänen 2001), there is no explicit passage concerning the Cosmic Pillar in the preserved mythological texts, but there are several indications that the theme must have been of great importance. Furthermore, there is an abundance of evidence of upraised poles and posts, constituting cultic replicas of the Cosmic Pillar in ritual contexts. For example, in the account from 922 CE by Ibn Fadlan, mentioned above, we find that the rus' suspended parts of sacrificed animals on upraised posts. Some of these posts were decorated with faces, depicting the gods of the rus' (Ibn Fadlan; cf. Wikander 1978, 64-5). Similar practices are also attested as occurring in the Danes town of Haithabu (Hedeby, Schleswig) by Ibrahîm ibn Ahmed at-Tartûschî 973 CE, according to the Arab historiographer Qazwînî (Arabische Berichte 1927, 29). Several accounts, the earliest from $806 \mathrm{CE}$, mention a cultic post among the 
Saxons, called Irminsûl. According to the monk Rudolf from the monastery of Fulda, writing in $865 \mathrm{CE}$, the Saxons maintained that Irminsûl was a universalis columna, quasi sustinens omnia, 'a cosmic pillar, as it supported the universe' (Rudolf, 1925, 676). ${ }^{4}$ Cultic posts are also attested in numerous Scandinavian compound place-names containing as one element the form stafr 'staff, pole', as well as in some medieval Scandinavian provincial laws concerning heathen practice. In many of these cases the Cosmic Pillar and the cultic replicas were partly merged in a larger complex of motifs, conceptions and ritual practices. ${ }^{5}$

The motif of the Cosmic Mountain is not absent in the Old Norse texts, although it does not seem to have been of such extensive importance as the Cosmic Tree. The theme is most elaborately depicted in a myth preserved by Snorri Sturluson in Skáldskaparmál (ch. G57-G58; Snorri's Edda 1998, 3ff.), concerning Óðinn's theft of the cosmic mead (identified with the liquid in the Cosmic Well) that was hidden deep inside the mountain Hnitbjorg 'the mountains that shuts with a clash' (cf. Drobin 1991, 112-7). It is probable that there was both a micro- and a macrocosmic relationship between the conception of the Cosmic Mountain and certain sacrificial sites, similar to that between the mythological and cultic trees and pillars. Many archaeological findings from the Bronze and Iron Age testify that sacrifices and offerings were deposited at the base of rocks and boulders (cf. Biuw 1992, 134; Kaliff 2007, 114-9; Lindeblad \& Petersson 2009). These rocks and boulders should be regarded as functional variants of the sacrificial trees and poles.

Furthermore, some Scandinavian place-names confirm that the gods were sometimes associated with certain mountains. In some instances, cultic sites were located on mountain crests. Such a site has been excavated at Odensala (in 1291 Othinshargh; the latter component ON. horgr means 'cult site, sanctuary, sacred stone monument', etc, the name thus 'Oðinn's sanctuary') in the province of Uppland, Sweden. A stone enclosure some $45 \times 60$ meters in size was built on a hilltop. Inside the enclosure were 26 'grave-shaped' stone monuments; since, however, they all contained a great deal of burnt animal bones and cultivated plants, but only two of them a small amount of human remains, it is likely that the structures should not

4 Furthermore, the Norse Cosmic Tree and Cosmic Pillar could well be studied in an Eurasic perspective. For Norse-Finnish parallels, see Drobin \& Keinänen 2001, for Eurasian counterparts, see Holmberg 1922.

5 Moreover, according to Old Norse texts, when the Scandinavian settlers in Iceland claimed their rights of possession to new pieces of land, they erected decorticated poles in the ground (Strömbäck 1970). It is reasonable to assume that by this custom, the new lands were 'cosmologized' and incorporated into Miðgarðr, the inhabitable world. 
be regarded as graves but as some kind of sacrificial constructions. The site seems to have been used during the first millennium BCE (Olausson 1995), although similar ritual stone enclosures elsewhere testify that this type of monument was in use during the first millennium CE as well. Many of these have grave-shaped monuments within the enclosures as well (Johansen 1997, 118-26).

\section{Cult Monuments and Graves}

Stone monuments similar to graves erected at cult sites have also been confirmed elsewhere. In Ringeby, close to Norrköping in the province of Östergötland, Sweden, graves and grave-shaped stone structures were situated in an area which was simultaneously used as a cult site during the first millennium BCE (Kaliff 1997). In Lunda (meaning '[sacred] grove'), close to Strängnäs in the province of Södermanland, Sweden, 58 graveshaped stone monuments (so-called 'stone settings', Swedish stensättning) were constructed on a hillock next to a major farmstead founded in the fifth century CE. The monuments contained very few human remains, but a huge amount of fragmented and crushed burnt animal bones were scattered over the hillock, as well as small drops of resin and crushed pieces of burnt clay. It is likely that this hillock was the actual lundr, the holy grove (Andersson 2006). A grave-shaped stone structure had also been erected at the recently excavated cult site at Götavi (-vi, Old Swe. ve, 'holy site') in the province of Närke in Sweden. This cult site, built in a wetland (thus the element Göta-, meaning 'outflow'), was in use during the Viking Age (Svensson 2008).

It thus seems as though certain types of monuments, commonly interpreted as graves, shared some architectonic features with monuments associated with other forms of ritual practice. The connection between graves and cult monuments has in recent years been extensively discussed by Anders Kaliff, who has suggested that the ritual monuments, as well as some graves, might in fact have been sacrificial altars (Kaliff 1997; 2007). Another very interesting idea has been put forward by Anders Andrén (2004) regarding a certain kind of 'three-pronged' stone construction (Swe. noun treudd). The three-prong is a monument shaped as a three-pointed star, with inward-curving sides. They are often found in central areas in Iron Age grave-fields from about 200-1050 CE in eastern Norway and in southern and central Sweden. But they also frequently occur solitarily at prominent locations in the landscape. When they do occur in grave-fields, there are 
always just one or very few of them on each site; while they often contain burials, many of them (about 35 \%) do not. In 1963, Märta Strömberg put forward the idea that the three-prong, in addition to a grave, might in fact be some form of cultic monument (Strömberg 1963). Based on this proposition, together with the fact that the post-holes or foundations of upraised stones or poles are often found at the center of a three-prong, and that they sometimes actually seem to have been built around actual trees, Andrén has suggested that the three-prongs could in fact have been erected as representations of the Cosmic Tree, in which the tree, pole or upraised stone symbolized the Cosmic Tree's trunk and branches, with the monument's three prongs as its three roots.

I believe that the idea proposed by Andrén is correct. I also believe that his interpretation may have even further implications for our understanding of the religious symbolism inherent in Iron Age grave architecture.

Erecting a grave was probably followed by certain ritual practices. I suggest that these rituals were in part of a cosmological nature, and that some cosmological symbolism was therefore built into the monuments' architecture. If this is so, however, the symbolism would still be very difficult for us to understand today, for many reasons. For instance, grave architecture varies in time as well as in space, making it reasonable to suggest that the symbolic meaning (if any) was diverse as well (compare Svanberg 2003). Then again, it is not impossible that these differences were actually varying ways to express similar conceptions. To interpret symbolic expressions in the architecture of ancient graves is therefore a risky business, and we will probably never understand all the information encoded in their construction. Having said this, however, I suggest that our possibility of understanding is the greater, the more important and common the ideas alluded to by the symbolism. I further propose that one of the most important notions associated with the grave was its function as a cosmic center, a link to the Other World, and that the idea of the World Axis was in fact in various ways built into the architecture of several types of grave monuments.

\section{Religious Symbolism in Central Boulder Graves}

A common feature in many Bronze and Iron Age graves in Scandinavia is the boulder. This architectonic element is found in several types of graves, although it is most prominent in the categories of monuments called 'boulder graves' (Swedish blockgrav) and 'central boulder graves' (mittblocksgrav) (Figure 2). In the following I focus on central boulder graves, but the impli- 
cations of the argument, I believe, apply to most types of monuments with boulders as prominent features.

The central boulder grave is more or less circular in shape. Usually one or several layers of stones have been packed around the boulder, while the empty spaces between the stones are filled with soil and pebbles. The monuments usually vary in size from a couple of meters to 10-12 meters. They occur as early as the second millennium BCE, but are most frequent in the younger Bronze Age and the early Iron Age (about 1000 BCE - 400 $\mathrm{CE}$ ) in east-central Sweden. Sporadically they occur well into the Viking Age (Bennett 1987, 64-5; Feldt 2005, 110-20).

As in the case of the three-prongs, the central boulder graves occur in grave-fields as well as solitarily at prominent locations in the landscape. When buried human remains are found in this type of monument, they are almost always from male individuals. The cremated deposits are usually placed in the southern part of the grave, preferable on the south side of the central boulder. ${ }^{6}$ Remarkably often, however, central boulder graves lack any remains of burials - actually even more so than the three-prongs. The central boulder graves too are thus apparently manifestations of something more than mere graves, in the present-day sense of the word. I suggest that the central boulder grave in fact may have had a significance similar to the three-prongs, and that the former may have been superseded by the latter.

If this is correct, it is probable that the monuments' central boulders had an essential architectonic meaning. A solution that lies near at hand is that the central boulders - as with the sacrificial stones - should be regarded as a form of micro-cosmic representation of the Cosmic Mountain. This idea is further strengthened by certain passages in Old Norse literary sources, for instance, in the story of Sveigðir, one of the semi-mythical kings of the Swear, who supposedly lived in the third or fourth century CE (although it is doubtful whether he actually existed). The episode is mentioned in a stanza of the poem Ynglingatal by Pióðólfr from Hvin, dated with some likelihood to around 870 CE (st. 2, cf. Noreen 1925, 198-9), and preserved in Snorri Sturluson's Ynglingasaga (ch. 12) from about 1220 (ÍF 26, 1979, 27). The latter source also gives a more comprehensive account of the episode. It is told that Sveigðir traveled far and wide in Goðheimr, 'the home or world

6 Compare the so called sydvästportar, mentioned above. The south to south-west direction most probably had a symbolic meaning. In Old Norse cosmology, the Other World was situated in the North. It is thus possible, that it is rather the northern direction which is marked here, the 'movement' being oriented from the south/south-west to the north (Nordberg 2008, 261). 
of the gods', in search of the god Óðinn. The mythological implication of this is presumably that Sveigðir was in fact seeking his own death, since Óðinn was the god of the dead; only in death could men join the gods in the Other World. One night, Sveigðir arrives at a farm called Steinn ('Stone', 'Rock'), situated by a huge rock. Sveigðir is invited to a feast, at which he gets extremely drunk. Later that night, making his way out into the courtyard, he sees a dwarf sitting under (undir) the rock. Sveigðir runs towards the dwarf, who is now standing in the 'door' (i dúra) of the rock. The dwarf exhorts Sveigðir, if he still wants to meet Óðinn, to follow him into the rock. Sveigðir does so; whereupon the rock's door shuts, and Sveigðir is never to be seen again.

The motif with the opening and shutting boulder in this episode is probably a variant of the Clashing Rocks theme. This is also found elsewhere in the Old Norse texts, as well as in later folklore (Hartmann 1937). In for example the Eyrbyggja saga, preserved in an Icelandic manuscript from about 1350 (Simek \& Pálsson 1987, 79), a farm is mentioned situated close to a mountain called Helgafell 'holy mountain'. It is told that the inhabitants of the farm believed that they were to dwell in that mountain after death, and that sometimes an opening into the mountain could be seen when someone on the farm had died (ÍF 4, 1935, 9, 19).

These episodes are either mythological or more or less folkloristic in character. Still, it is possible that glimpses of a core of pre-Christian religious conceptions can be found concealed in the late narrative form. In all three accounts, the rock or mountain offers a passage to the Other World. In some Old Norse texts, this is in fact also found in connection with graves and boulders in graves. For example, in the mythological poem Gróagaldr 'The charm of Gróa', preserved in manuscripts from the thirteenth and fourteenth century (Simek \& Pálsson 1987, 121) but based on older oral traditions, the young Svipdagr calls upon his dead mother to rise from the grave. Svipdagr chants (st. 1, Edda 1927, 298, my translation):

Vaki pú, Gróa!
vaki pú, góð kona!
vek ek pik dauðra dura:
ef pu pat mant,
at pú pin mogg bæðir
til kumbldysiar koma.

Wake up, Gróa!

Wake up, good woman!

I awake you at the door of the dead;

if you this remember, that you urged your son, to come to your grave-mound. 
Gróa is awakened, and answers (st. 2, Edda 1927, 298):

Hvat er nú ant mínom einga syni hverio ertu nú bǫlvi borinn, er pú pá móður kallar, er til moldar er komin ok ór lióðheimom liðin?
In what need is my only son? What evil is over you, when you call up your mother, who has turned into dust, and has left the world of men?

Svipdagr explains to his mother that she has been summoned in order to sing protective charms for him in preparation for a long and dangerous journey. From the context of the poem, it is clear that the journey's destination is the Other World. Gróa sings a galdr - a charm sung in a high and shrill voice - over Svipdagr, ending with the words (st. 15, Edda 1927, 301, my translation).
Á iarðfǫstom steini
On a stone fixed in the ground, stóð ek innan dura, I stood in the doorway, meðan ek pér galdra gól. while I over you galdrar chanted.

While this episode is situated in a semi-mythical context, it is likely that the content can to a large extent can be compared to the actual practices of necromancy, mentioned at the beginning of this article. By chanting standing on top of a grave or from a stone fixed in the ground, it was thought to be possible to summon or in other ways make contact with the dead. Similar practices, in which the importance of the boulder is again mentioned, are also attested for instance among the Finns (DuBois 1999, 32-3). ${ }^{7}$ In Gróagaldr it is the dead woman herself who chants galdrar from her grave, standing on a ground-fixed stone. And she does so, as the poem has it, 'standing in the doorway' in 'the door of the dead'. The meaning of this, I suggest, can only be that the grave and the ground-fixed boulder are regarded as 'doorways' between this and the Other World.

In my view, it is not farfetched to draw a parallel between the significance of the rocks and boulders in these (semi-) mythological narrations and the possible symbolic meaning of the (central) boulders in Late Bronze and Iron Age graves. The Old Norse manuscripts in which motifs with a rock as a passage to the Other World are preserved are certainly much younger than the graves in question. But this is not crucial. The motifs and

7 Furthermore, Old Norse mythological conceptions of death, the Afterlife and the Other World in general share many features with other religions over the Eurasian and the IndoEuropean area. 
conceptions in question occur in a variety of contexts in many parts of the world and across a long period of time (cf. Holmberg 1922); furthermore, motifs and conceptions of death and the afterlife generally seem to change very slowly (Ariés 1983). The rocks and boulders both in the Old Norse sources and in the archaeologically verified graves should in all probability be regarded as representations of the world axis, the connecting link to other cosmic worlds. As such, the boulders in graves hold an architectonic symbolism, very similar to the boulders used in sacrifices and other kinds of ritual practices.

\section{Religious Symbolism in the Architecture of the Round Stone Setting}

The most common architectonic form of pre-Christian grave is a type of monument generally known as 'round stone setting'. This type of monument was already in use in the early Bronze Age (about 12-1100 BCE), and well into the last centuries of the pre-Christian era in Scandinavia (eleventh century CE). Geographically, it is attested in most parts of the 'Germanic' part of Sweden and Norway, as well as in Denmark and northern Germany and in the previously Germanic areas of what is now Poland. This widespread occurrence of round stone settings makes the type interesting: is a variant of the symbolism found in the three-prongs and (central) boulder graves present in the architecture of the round stone settings as well?

I try to answer this question by analyzing two round stone settings at a grave-field at Sylta, about 20 kilometers north of Stockholm in Sweden (Fresta parish, Uppland), which was the subject of extensive excavations by the Swedish National Heritage Board during 2003-2004, in which I took part (cf. Andersson \& Svensson 2005). For the sake of clarity, let me identify the two stone settings as Grave 1 and Grave 2 (Figure 3). ${ }^{8}$ Both graves were erected about $500 \mathrm{CE}$. They were elaborately constructed and circular in shape, with a diameter of about five meters. For the most part they were built of stone, but the stone packings were covered with a layer of gravel and soil. The center in both graves was marked by a large flat stone. This form of round stone setting usually signifies a female burial (male graves normally give a 'rougher' impression and are usually built of larger stones) (Bennett 1987,147); since in addition a female finger ring was found in Grave 1 , we can assume that the two graves were erected over women. In both cases the dead had been cremated.

8 In the archaeological report (Andersson \& Svensson 2005) the two graves are identified as AG 563 and AG 615. 
To interpret the architectonic symbolism in these graves, it is relevant to examine their successive building phases (for a more extensive analysis see Nordberg 2008).

\section{The Area is Inaugurated by Fire}

The first thing to be done in erecting a grave was probably to clear the surface of stones, brushwood, turf and topsoil. This was apparently done in part by means of fire: beneath graves from the early Iron Age in Sweden (about $500 \mathrm{BCE}-500 \mathrm{CE}$ ) we commonly find thin leached lenses of soot (Bennett 1987, 86; Hamilton 2003, 14). This was also the case in the two graves in question here. These soot lenses should not be confused with the charcoal layers containing cremated human and animal remains found in graves from later periods, although soot lenses are sometimes found in late Iron Age graves as well. The soot lenses probably arose in the process of burning off vegetation and root systems from the area of the grave under construction. If so, the reasons for the burn-beating of the ground were at least in part practical.

On the other hand, it is likely that the burning had religious connotations as well (compare Anttonen 1992, 58-9). In pre-Christian Scandinavia fire was used to inaugurate new pieces of land, either by carrying fire alongside the borders of the new area or by lighting fires on the new land. Similar rituals were practiced in Scandinavia many centuries into the Christian era (Ejdestam 1944, 129-37; Strömbäck 1970; cf. Bertell 2003, 211-41). Furthermore, in many Old Norse texts, as well as in later folklore, it is testified that fire and fire-places were sometimes thought of as intermediary places connected to the Other World. In many sources these fires - on occasion called Helseldar 'the fires of the Kingdom of death' - are said to be burning in or upon grave mounds (cf. Ellis 1943, 174-85). In the twelfth-century poem Hervararkviða, for example, when Hervor is said to be summoning her father Heiðrekr from his grave, she finds herself 'between the worlds' (heima i millum), with fires burning all around her (cf. Tolkien 1997, 22). Episodes like these are of course depicted in a literary manner, for purposes of entertainment; nevertheless, they should probably be seen in parallel with some archaeologically attested fires connected with graves. Fires, for example, were sometimes lit in the ditches surrounding graves from the latter half of the Iron Age, seemingly during some part of the death cult (Lögdqvist 2009, 54). It is thus possible that the burn-beating of the ground in the area where a grave was to be erected might in fact have been connected with similar ideas. 


\section{The Grave Area is Marked off and a Link to the Other World is Created}

When the area had been cleared and inaugurated, the next step in the building process was apparently to mark off the inside of the grave from its outside surroundings (cf. Anttonen 1992). This was done by constructing a circular enclosure of stones, which was later to become the outer edge of the grave. The two graves at Sylta (as well as a large number of round stone settings elsewhere) were almost perfectly circular. This was probably achieved by driving a post into the ground at the center of the grave area and then marking out a circle around it by means of a cord tied to the post. Sometimes, as in Grave 1, this method is apparently confirmed by a small post-hole in the grave's center.

It is likely - in fact, as we shall see, sometimes obvious - that the pole at the center of the grave was left standing during the funeral and the process of constructing the monument. This indicates that the upraised pole may have had a specific symbolic meaning. As already mentioned, upraised poles were of great importance in pre-Christian religion. In sacrificial practices, sacrificial gifts were suspended in or deposited at the feet of poles and posts, representing the World Pillar or World Tree. Upraised posts in graves should probably be understood in a similar way. The posts may have served as a ritual attribute representing the World Axis.

\section{Depositing Human Remains in the Graves}

Ways of handling human remains varied during the Iron Age. During the period of the two graves discussed here, the deceased were generally cremated and the burnt bones collected and crushed into small pieces before being deposited in the graves. Usually, however, only a small proportion of the cremated bones were actually buried in the grave. This phenomenon has given rise to much debate among archeologists. It has been suggested that the major part of the remains was distributed over arable land or deposited in a nearby holy lake (cf. Kaliff 1997, 90-2). But these are merely guesses: what was done with the major part of human remains is still an unsolved question. The remains that did in fact end up in graves were deposited in several different ways. Sometimes the burnt bones were placed in a small hole in the ground, sometimes they were scattered over the inside area of the monument. Frequently, different methods were combined (Bennett 1987, 78-80).

In the two stone settings at Sylta, both methods were used. In Grave 1, most of the deposited burnt bones were distributed over the soot lens at the 
foundation of the grave, especially in its central area close to the upraised post. Some burnt bones, however, were saved for later deposition. In Grave 2 , only a small amount of burnt bones was spread out over the soot lens. The major part was deposited in a small cup-shaped hole (about a decimeter wide and deep), in the ground inside the grave. This hole was placed close to the center of the grave - as were most other similar deposits with cremated bones in the round stone settings at Sylta. In no case, however, were the bones deposited in a pit situated at the absolute center of the monument. This indicates that the pits were dug and the remains deposited with reference to the upraised central posts. This too, I propose, may have carried an important symbolic meaning.

\section{Creating a Stone Construction above the Deposited Remains}

As the next step in the construction process, a small stone structure was built above the bone deposit. The most elaborate of these structures was found in Grave 1 (see Nordberg 2008, 268, Figure 5). The construction was more or less square in shape, with sides of about 1.2 meters. A stone of red granite was placed at each corner. These corner stones enclosed layers of smaller sized stones, except for the center, where a circular-shaped hollow had been created. This hollow encompassed the central post-hole, which again suggests that the upraised post was left standing during the construction process and that the stone structure was in fact built around it. Between and over the structure's stone layers, the remainder of the cremated bones was scattered. The purpose of the circular hollow is not clear. It was apparently empty, but perhaps it had originally been built as a place to deposit gifts and offerings for the buried woman on later occasions. As one of the final steps in the building process, a large flat stone in red granite was placed as a closure over the hollow.

The stone structure in Grave 2 was of a more ordinary kind (see Nordberg 2008, 269, figure 6). A stone cist, rounded and about 0,7-0,8 meters wide, had been constructed above the pit containing the burnt bones. As in Grave 1, the cist was covered by a flat stone, which hypothetically could have been used as a 'lid' over the structure. If gifts such as food offerings were deposited inside the hollow space, it would have been placed precisely above the remains of the dead. 


\section{Enclosure of the Graves by a Stone Layer in a Counterclockwise Direction}

When the central stone structures were completed, what was left inside the circular stone enclosure was covered with a layer of stones. Interestingly enough, it was possible to establish during the excavation that this occurred in several different sequences. Such patterns in the stone packing of graves have been recognized elsewhere as well. Why they occur is not yet clear, but one possibility is that the stone packings were put together by different participants in the funeral. Furthermore, the stone packings in the two graves were filled with stones in a counterclockwise direction, i.e. contrary to the movement of the sun. This was established in so many graves at Sylta as to make it highly probable that the counterclockwise direction was deliberate (see Nordberg 2008, 270-1, figure 8).

This choice of a direction opposite to the course of the sun had a certain symbolic meaning. According to some widespread conceptions, what was connected to death and the World of the Dead was reverse, upside-down and opposite to its counterparts in the world of the living. For this reason, practices associated with death and the dead were expected to be performed backwards, upside-down or counter-clockwise (cf. Holmberg 1925 for the most elaborate exploration of these ideas). Similar motifs are attested already in the Odyssey and the Egyptian Book of the Dead. In pre-Christian Scandinavia the idea is depicted for example in a representation of a funeral on a Gotlandic picture-stone at Tängelgårda in Lärbro parish, dated to the eighth century (Lindqvist 1941, 99). In the scene, a procession of men is striding behind a horse, which is carrying a fallen warrior. The horse has eight legs, suggesting that it is a representation of Óðinn's horse Sleipnir, who carries the dead to the Other World. The horse is wearing a hood over its head. In later periods, horses in funeral processions had their eyes covered because the gaze of horses bearing the dead or drawing a funeral hearse was thought to be lethal (Lindqvist 1941, 99). What is most interesting, however, is the fact that the men in the procession are walking backwards and carrying their swords upside-down. In a similar scene on a tapestry found in a burial ship from the mid-ninth century at Oseberg in Vestfold, Norway, a group of men in a funeral procession are carrying their spears in the same reverse way (Steinsland 1997, 110-2). According to Ibn Fadlan's account of a chieftain's funeral among the rus', mentioned earlier, the person lighting the funeral pyre was expected to be naked, approaching the pyre with a torch in one hand and the other hand covering his anus walking backwards (Ibn Fadlan, cf. Wikander 1978, 68-9). In pre-Christian practices of sorcery and divination, the acts were supposed to be carried out in a counter-clockwise 
direction (Bø 1966). Similar observances continued to be practiced far into the Christian era (cf. Celander 1928, 222-5; af Klintberg 1965, 31-2).

At Sylta, several graves were built at least partly in an counter-clockwise direction. I consider it probable (although it is naturally merely a hypothesis), that this was because certain practices associated with death, the dead and the Other World were supposed to be carried out in this kind of reverse manner.

\section{Closing of the Grave}

As the final step in the construction process, the grave was covered by thick layers of sand and gravel. At this moment, the upraised post in Grave 1 was finally removed and replaced by the large flat stone in red granite that enclosed the hollow in the central square structure. It was impossible to establish whether the post in Grave 2 was left standing after the construction was completed, or whether it was removed at this final stage. There are some slight indications of the latter possibility. In the top soil covering the layer of sand and gravel, a large flat stone was found close to the center. As in Grave 1, this stone might originally have marked out the center of the grave after the monument was completed. On the other hand, in several graves elsewhere the central posts seem to have been left standing (see below).

\section{The Grave and the Representation of the World Axis}

One important architectonic component in the construction of the round stone setting was the upraised post. In my view, this post can be seen as a representation of the World Pillar, analogous to the sacrificial posts erected at pre-Christian cult sites. Interestingly enough, upraised posts are attested in yet another type of grave monument: the grave mound, frequently occurring in Scandinavia during the last half millennium of the pre-Christian era.

From the fourth century and onwards (about 300-1000 CE), several large mounds, with a flat crest and an upraised pole at the center, were raised in Scandinavia. Like the central boulder graves and three-prongs, in many cases these too lack depositions of human remains. For instance, the southern large mound at Jelling, Denmark was built around an elm-pole that had been driven into the ground. This pole was extended with a second pole, in order to reach the top of the grave (Krogh 1993, 257-60). As this construction detail had no practical function whatsoever, it most likely had a symbolic 
meaning. At Himlingøje in Denmark a central pole was erected inside one of the largest mounds at the site. This monument did not contain burial depositions; in another mound, however, cremated human remains were found next to an upraised pole at the center of the grave. At Vorbjerg and Slotsbjerg in Denmark, the charred remains of upraised poles were found in post-holes underneath the center of the mounds. In the western king'smound at Old Uppsala in Sweden, a pole of hardwood had been raised up at the center; in a similar way, two poles of birch were erected at the center of a large mound at Staby in Swedish Uppland (Lindqvist 1936, 30, 146-7). At Björkå in the province of Ångermanland, Sweden, a large mound was built around an upraised pole. A mound known as Farmannshaugen, at Tønsberg, Vestfold in Norway, was similarly constructed around an upraised pole of ash wood (Andersen 1951).

These monuments are all large mounds. In many cases they do not contain burials, and several of them have flat crests. Since the majority of this type of large flat-crested monuments are situated close to medieval churches, it has been suggested that they should be regarded as something else, or at least something more, than mere graves. Several scholars have put forward the idea that this type of monument was associated with cultic activities, regional council meetings and the coronations of new leaders (cf. Lindqvist 1936; Andersen 1951).

This, I believe, may be correct. But upraised poles are also attested in ordinary mounds that do contain depositions of human remains. It is known from archeological records in Scandinavia, as well as from the area of the Danelaw in Britain (Sanmark 2004, 166), that central posts were erected in Iron Age grave mounds well into the Viking Age. This is also confirmed in some written sources. Ibn Fadlan, for instance, reports that the Norsemen incorporated upraised posts in their grave mounds, and that the names of the buried were sometimes carved into them (Ibn Fadlan, cf. Wikander 1978, 69). Furthermore, post-holes for upraised posts are a common feature in Scandinavian Iron Age grave-fields. Since these post-holes rarely seem to be part of a larger structure, it is possible that the posts were associated with cultic activities.

In my view, such structures as the upraised posts, standing stones, (central) boulders and built-in trees in the Iron Age monuments here discussed may be varying expressions of the same idea: they can be seen as representations of the concept of the World Axis, manifested in myth in the form of the Cosmic Tree, the Cosmic Pillar and the Cosmic Mountain. These differing versions do not involve a contradiction. On the contrary: the 
variation proves that the underlying idea was important. Of course, we cannot know that the architectonic symbolism of the upraised posts, standing stones, built-in trees and boulders remained unchanged over the long time period in question. Changes and variations most probably did occur. The evidence, however, suggests that the core conception is an old one. It also suggests that the symbolism did not vary with gender or social status. The grave was a 'gateway' to the Other World: one that all human beings had to enter at the hour of death, irrespective of their social status in life.

\section{Bibliography}

\section{Adam av Bremen}

1984 Historien om Hamburgstiftet och dess biskopar. Översättning av Emanuel Svenberg, kommentar av Carl Fredrik Hallencreutz. Stockholm: Proprius. (Skrifter utgivna av Samfundet Pro fide et christianismo.)

\section{Alkarp, Magnus}

1997 Källan, lunden och templet - Adam av Bremens Uppsalaskildring i ny belysning. - Fornvännen 92, 155-61.

\section{Andersen, Harald}

1951 Tomme høje. - KUML, 91-135.

\section{Andersson, Gunnar}

2006 Among Trees, Bones and Stones: The Sacred Grove at Lunda. - Anders Andrén \& Kristina Jennbert \& Catharina Raudvere (eds), Old Norse Religion in Long-Term Perspective: Origins, Changes, and Interactions, 195-9. Lund: Nordic Academic Press. (Vägar till Midgård 8.)

\section{Andersson, Gunnar \& Susanne Svensson}

2005 Gravfält vid Lilla Sylta. Norrortsleden. Uppland, Fresta socken, Stora Alby 1:75, RA Ä 87:1-2. (Riksantikvarieämbetet UV mitt, Daff.)

\section{Andrén, Anders}

2004 I skuggan av Yggdrasil. Trädet som idé och realitet i nordisk tradition. - Anders Andrén \& Kristina Jennbert \& Catharina Raudvere (eds), Ordning mot kaos. Studier av nordisk förkristen kosmologi, 389-430. Lund: Nordic Academic Press. (Vägar till Midgård 4.)

\section{Anttonen, Veikko}

1992 Interpreting Ethnic Categories Denoting 'Sacred' in a Finnish and an Ob-Ugrian Context. - Temenos 28, 53-80. 


\section{Arabische Berichte}

1927 Arabische Berichte von Gesandten an germanische Fürstenhöfe aus dem 9. und 10. Jahrhundert. Ins Deutsche übertragen und mit Fußnoten versehen von Georg Jacob. Berlin \& Leibzig: Walter de Gruyter \& co. (Quellen zur deutschen Volkskunde 1.)

\section{Ariès, Philippe}

1983 The Hour of Our Death. Translated from the French by Helen Weaver. Harmondsworth: Penguin.

\section{Arrhenius, Birgit}

1970 Tür der Toten. Sach- und Wortzeugnisse zu einer frühmittelalterlichen Gräbersitte in Schweden. - Frühmittelalterliche Studien 4, 384-94.

\section{Bauschatz, Paul C.}

1982 The Well and the Tree: World and Time in early Germanic Culture. Amherst: University of Massachusetts Press.

\section{Bennett, Agneta}

1987 Graven. Religiös och social symbol. Strukturer i folkvandringstidens gravskick i Mälarområdet. Stockholm: Stockholms universitet. (Theses and Papers in North-European Archaeology 18.)

\section{Bertell, Maths}

2003 Tor och den nordiska åskan. Föreställningar kring världsaxeln. Stockholm: Stockholms universitet.

Biuw, Agneta

1992 Norra Spånga. Bebyggelse och samhälle under järnåldern. Stockholm: Stockholms stad. (Monografier utgivna av Stockholms stad.)

\section{Bø, Olav}

1966 Motsols. - Kulturhistoriskt lexikon för nordisk medeltid 11,711-2. Malmö: Allhem.

\section{Celander, Hilding}

1928 Nordisk jul. Julen i gammeldags bondesed. Stockholm: Geber.

\section{Drobin, Ulf}

1991 Mjödet och offersymboliken i fornnordisk religion. - Louise Bäckman \& Ulf Drobin \& Per-Arne Berglie (eds), Studier i religionshistoria tillägnade Ake Hultkrantz professor emeritus den 1 juli 1986, 97-142. Löbberöd: Bokförlaget Plus Ultra.

\section{Drobin, Ulf \& Marja-Liisa Keinänen}

2001 Frey, Veralden Olmai och Sampo. - Michael Stausberg (ed.), Kontinuitäten und Brüche in der Religionsgeschichte. Festschrift für Anders 
Hultgård zu seinem 65. Geburtstag am 23.12.2001, 136-69. Berlin \& New York: Walter de Gruyter.

DuBois, Thomas, A.

1999 Nordic Religions in the Viking Age. Philadelphia: University of Pennsylvania Press.

\section{Edda}

1927 Edda. Die Lieder des Codex Regius nebst verwandten Denkmälern. Herausgegeben von Gustav Neckel. Heidelberg.

\section{Edda}

1983 Edda. Die Lieder des Codex Regius nebst verwandten Denkmälern. Herausgegeben von Gustav Neckel Band 1. Text. 5. verbesserte Auflage von Hans Kuhn. Heidelberg: Carl Winter Universitätsverlag.

\section{Edsman, Carl Martin}

1944 Arbor inversa. - Religion och Bibel 3, 5-33.

\section{Ejdestam, Julius}

1944 Arseldarnas samband med boskapsskötsel och åkerbruk $i$ Sverige. Uppsala: Landsmåls- och Folkminnesarkivet. (Skrifter utgivna genom Landsmåls- och Folkminnesarkivet i Uppsala. Ser. B:2.)

\section{Eliade, Mircea}

1959 The Sacred and the Profane: the Nature of Religion. Translated from the French by Willard R. Trask. New York: A Harvest/HBJ Book.

\section{Ellis, Hilda Roderick}

1943 The Road to Hel. A Study of the Conception of the Dead in Old Norse Literature. Cambridge: University Press.

\section{Feldt, Björn}

2005 Synliga och osynliga gränser: förändringar $i$ gravritualen under yngre bronsålder-förromersk järnålder i Södermanland. Stockholm: Stockholms universitet. (Stockholm Studies in Archaeology, 37.)

\section{Gennep, Arnold van}

1960 The Rites of Passage. Introduction by Solon T. Kimball; translated by Monika B. Wizedomand Gabrielle L. Caffee. Chicago: University of Chicago Press.

\section{Gräslund, Anne-Sofie}

1969 Särdrag inom vikingatidens gravskick. - Nord-svensk forntid, 13350. 


\section{Hamilton, John}

2003 Tomtebodagravfältet. Uppland, Solna sn., Polisen 2, RÄ̈ 39. (Riksantikvarieämbetet, UV Mitt, DAFF.)

\section{Hartmann, Elisaberth}

1937 Der Ahnenberg. Eine Altnordische Jenseitsvorstellung. - Archiv für Religionswissenschaft 34, 201-17.

\section{Holmberg (Harva), Uno}

1917 Valhall och världsträdet. - Finsk tidsskrift för vitterhet, vetenskap, konst och politik, 337-453.

1922 Der Baum des Lebens. Helsinki: Suomalainen tiedeakatemia. (Annales Academiae scientiarum Fennicae. Ser. B.)

1925 Vänster hand och motsols. - Rig 8, 23-36.

\section{Hultgård, Anders}

1993 Altskandinavische Opferrituale und das Problem der Quellen. - Tore Ahlbäck (ed.), The Problem of Ritual, based on papers read at the Symposium on Religious Rites held at Abo, Finland, on the $13^{\text {th }}-16$ th of August 1991, 221-59. Åbo: Donner Institute for Research in Religious and Cultural History.

\section{Hultkrantz, Åke}

1996 A New Look at the World Pillar in Arctic and sub-Arctic Religions. - Juha Pentikäinen (ed.), Shamanism and Northern Ecology, 31-50. Berlin: Mouton de Gruyter.

\section{ÍF 4}

1935 Íslenzk fornrit IV. Eyrbyggja saga. Einar Ól. Sveinsson gaf út. Reykjavík: Hið íslenzka fornritafélag.

\section{ÍF 26}

1979 Íslenzk Fornrit XXVI. Snorri Sturluson Heimskringla. Bjarni Aalbjarnarson gáf út. Reykjavík: Hið íslenzka fornritafélag.

\section{Iregren, Elisabeth}

1989 Under Frösö kyrka - ben från vikingatida offerlund? - Lars Larsson \& Bozena Wyszomirska (eds), Arkeologi och religion: Rapport från arkeologidagarna 16-18 januari 1989, 119-33. Lund: Lunds universitet. (Institute of Archaeology. Report Series No. 34.)

\section{Johansen, Birgitta}

1997 Ormalur: aspekter av tillvaro och landskap. Stockholm: Stockholms universitet. (Stockholm Studies in Archaeology 14.) 


\section{Kaliff, Anders}

1997 Grav och kultplats: eskatologiska föreställningar under yngre bronsålder och äldre järnålder $i$ Östergötland. Uppsala: Uppsala universitet. (AUN 24.)

2007 Fire, water, Heaven and Earth. Ritual Practice and Cosmology in Ancient Scandinavia: An Indo-European Perspective. Stockholm: Riksantikvarieämbetet.

\section{Klintberg, Bengt af}

1965 Svenska trollformler. Stockholm: Wahlström \& Widstrand.

\section{Krogh, Knud J.}

1993 Gåden om Kong Gorms grav: historien om Nordhøjen i Jelling. Udgivet af Carlsbergfondet og Nationalmuseet: Poul Kristensens Forlag. (Vikingekongernes monumenter i Jelling Bind 1.)

\section{Lindeblad, Karin \& Maria Petersson}

2009 Riter vid berg, block och vatten. - Anne Carlie (ed.) Järnålderns rituella platser. Femton artiklar om kultutövning och religion från en konferens $i$ Nissaström den 4-5 oktober 2007. Halmstad: Kulturmiljö Halland.

\section{Lindqvist, Sune}

1936 Uppsala högar och Ottarshögen. Stockholm: Wahlström \& Widstrand. (Monografier: Kungl. Vitterhets-, historie- och antikvitetsakademien, 23.)

\section{Lindqvist, Sune}

1941 Gotlands Bildsteine I. Gesammelt und untersucht von Gabriel Gustafson und Fredrik Nordin; nach erneuter Durchsicht und Ergänzung des Materials herausgegeben von Sune Lindqvist. Stockholm: Wahlström \& Widstrand. (Kungl. Vitterhets Historie och Antikvitets Akademien 28.)

\section{Lögdqvist, Anna}

2009 Arkeologiska undersökningar. ISLINGBY: inför byggandet av infartsväg till SSAB Tunnplåt, RAA 22:1, 218:1 och 223:1. Dalarna: Borlänge stad och kommun. (Dalarnas Museum. Arkeologisk rapport 2009:1.)

\section{Meletinskij, Eleazar Moiseevič}

1973a-b Scandinavian Mythology as a System 1-2. - Journal of Symbolic Anthropology 1972:1-2.

\section{Nordberg, Andreas}

2004 Krigarna $i$ Odins sal. Dödsföreställningar och krigarkult $i$ fornnordisk religion. 2:a upplagan. Stockholm: Stockholms universitet. 
2008 Döden är ett kosmiskt drama. Religiös symbolik i gravarkitekturen på gravfältet i Sylta. - Michael Olausson (ed.), Hem till Jarlabanke. Jord, makt och evigt liv i östra Mälardalen under järnålder och medeltid, 248-72. Lund: Historiska media.

NGL

1846 Norges gamle love indtil 1387. Bd 1, Norges love ældre end Kong Magnus Haakonssöns regjeringstiltrædelse i 1263. Christiania: Udgivne ved Rudolph Keyser og Peter Andreas Munch.

\section{Noreen, Adolf}

1925 Ynglingatal. Text, översättning och kommentar av Adolf Noreen. Stockholm: Wahlström \& Widstrand. (Kungl. Vitterhets historie och antikvitets akademiens handlingar 28:2.)

\section{Olausson, Michael}

1995 Det inneslutna rummet: om kultiska hägnader, fornborgar och befästa gårdar i Uppland från $1300 \mathrm{f} \mathrm{Kr}$ till Kristi födelse. Stockholm: Riksantikvarieämbetet. (Studier från UV Stockholm.)

\section{Rudolf}

1925 Translatio S. Alexandri. Monumenta Germaniae Historica. Rerum Germanicarum Fontibus. tomus II. Leipzig: Editit Georgius Heinicus Perz.

\section{Sanmark, Alexandra}

2004 Power and Conversion. A Comparative Study of Christianization in Scandinavia. Uppsala: Uppsala universitet. (OPIA 34.)

\section{Schjødt, Jens Peter}

1993 The Relation between the two Phenomenological Categories Initiation and Sacrifice as Exemplified by the Norse Myth of Ódinn on the Tree. - Tore Ahlbäck (ed.), The Problem of Ritual. Based on Papers Read at the Symposium on Religious Rites Held at Abo, Finland, on the 13th-16th of August 1991, 261-73. Åbo: Donner Institute for Research in Religious and Cultural History.

\section{Simek, Rudolf \& Hermann Pálsson}

1987 Lexikon der altnordischen Literatur. Stuttgart: Alfred Kröner Verlag.

\section{Skj. B1}

1973 Den norsk-islandske Skjaldedigtning. Ved Finnur Jónsson. B. Rettet text. Første bind. København: Rosenkilde og Bagger.

\section{Snorri's Edda}

1988 Snorri Sturluson. Edda. Prologue and Gylfaginning. Edited by Anthony Faulkes. Viking society for Northern Research. London: University College. 


\section{Steinsland, Gro}

1997 Eros og død i norrøne myter. Oslo: Universitetsforlaget.

\section{Ström, Folke}

1947 Den döendes makt och Odin i trädet. - Göteborgs högskolas Årsskrift LIII, 1947:1. Göteborg: Göteborgs högskola.

\section{Strömberg, Märta}

1963 Kultische Steinsetzungen in Schonen. - Meddelande från Lunds universitets historiska museum 1962-1963, 148-85. Lund: Lunds universitets historiska museum.

\section{Strömbäck, Dag}

1970 Att helga land. Studier i Landnáma och det äldsta rituella besittningstagandet. - Folklore och filologi. Valda uppsatser Utgivna av Kungl. Gustav Adolfs Akademien 13.8 1970. Uppsala: Kungliga Gustav Adolfs Akademien. (Acta Academiae Regiae Gustavi Adolphi, 48.)

\section{Sundqvist, Olof}

2004 Uppsala och Asgård: makt, offer och kosmos i forntida Skandinavien. - Anders Andrén \& Kristina Jennbert \& Catharina Raudvere (eds), Ordning mot kaos. Studier av nordisk förkristen kosmologi, 145-82. Lund: Nordic Academic Press. (Vägar till Midgård 4.)

\section{Svanberg, Fredrik}

2003 Decolonizing the Viking Age I-II. Stockholm: Almqvist \& Wiksell International. (Acta archaeologica Lundensia. Series in $8^{\circ}, 43$.)

\section{Svensson, Kenneth}

2008 Götavi - en vikingatida kultplats? - Anna Lagerstedt (ed.) På väg genom Närke - ett landskap genom historien, 197-208. Upplands Väsby: Arkeologikonsult. (Rapporter från Arkeologikonsult 2008: 2025.)

\section{Tolkien, Christopher (ed.)}

1997 Hervarar Saga ok Heiðreks. With notes and glossary by G. Turville-Petre, introduction by Ch. Tolkien. Viking Society for Northern Research. London: University College.

\section{Turner, Victor}

1969 The Ritual Process: Structure and Anti-Structure. London: Routledge \& Kegan Paul.

1970 The Forest of Symbols: Aspects of Ndembu Ritual. Ithaca: Cornell U.P.

\section{Vries, Jan de}

1934 Odin am Baume. - Studia Germanica tillägnade Ernst Albin Kock den 6 december 1934. Lunder germanistische Forschungen. Lund: C. Blom. 


\section{Wall, Jan-Inge}

1989 Hon var en gång tagen under jorden. Visionsdikt och sjukdomsbot $i$ gotländska trolldomsprocesser. Uppsala: Dialekt- och folkminnesarkivet. (Skrifter utgivna genom Dialekt- och folkminnesarkivet i Uppsala. Ser. B, Folkminnen och folkliv.)

\section{Wikander, Stig}

1978 Araber, vikingar, väringar. Översatt och utgiven av Stig Wikander. Lund: Svenska Humanistiska Förbundet. (Svenska Humanistiska Förbundet 90.) 


\section{Appendix: Figures}

Figure 1. Map of Place-Names mentioned in the essay. Graphics: Paulina Tamme.

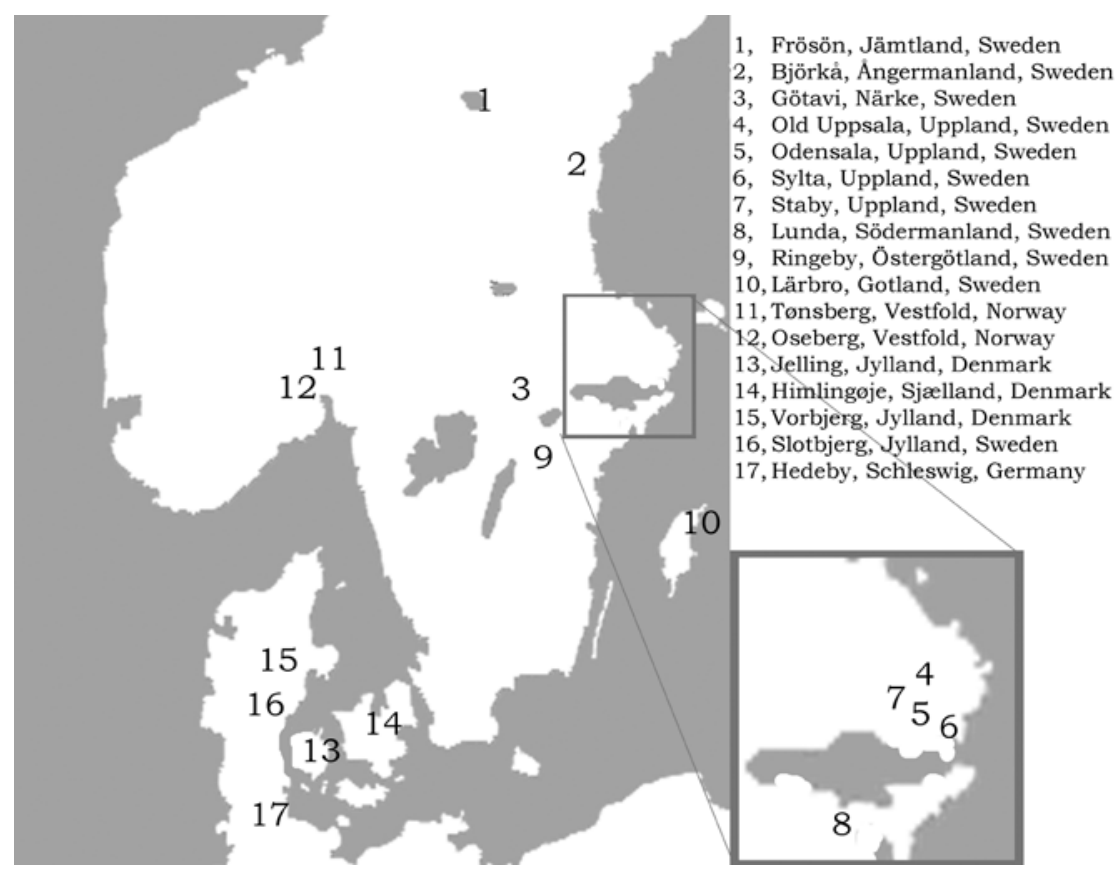


Figure 2. A central boulder grave at Lingsberg (RA 2421 Vallentuna parish), in Vallentuna, Uppland, about 25 kilometers north of Stockholm. Photo: Andreas Nordberg.

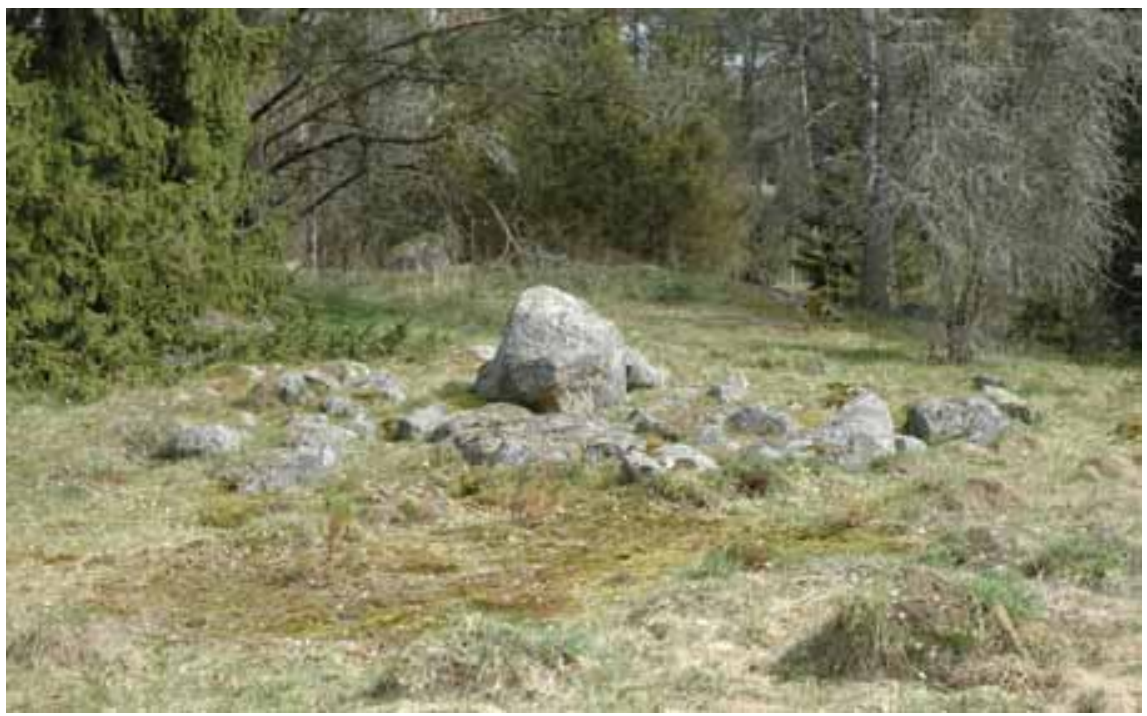

Figure 3. A round stone-setting at Sylta (RA Ä 87, Fresta parish), Uppland, Sweden, approximately dated to 500 AD. Photographer: Andreas Nordberg.

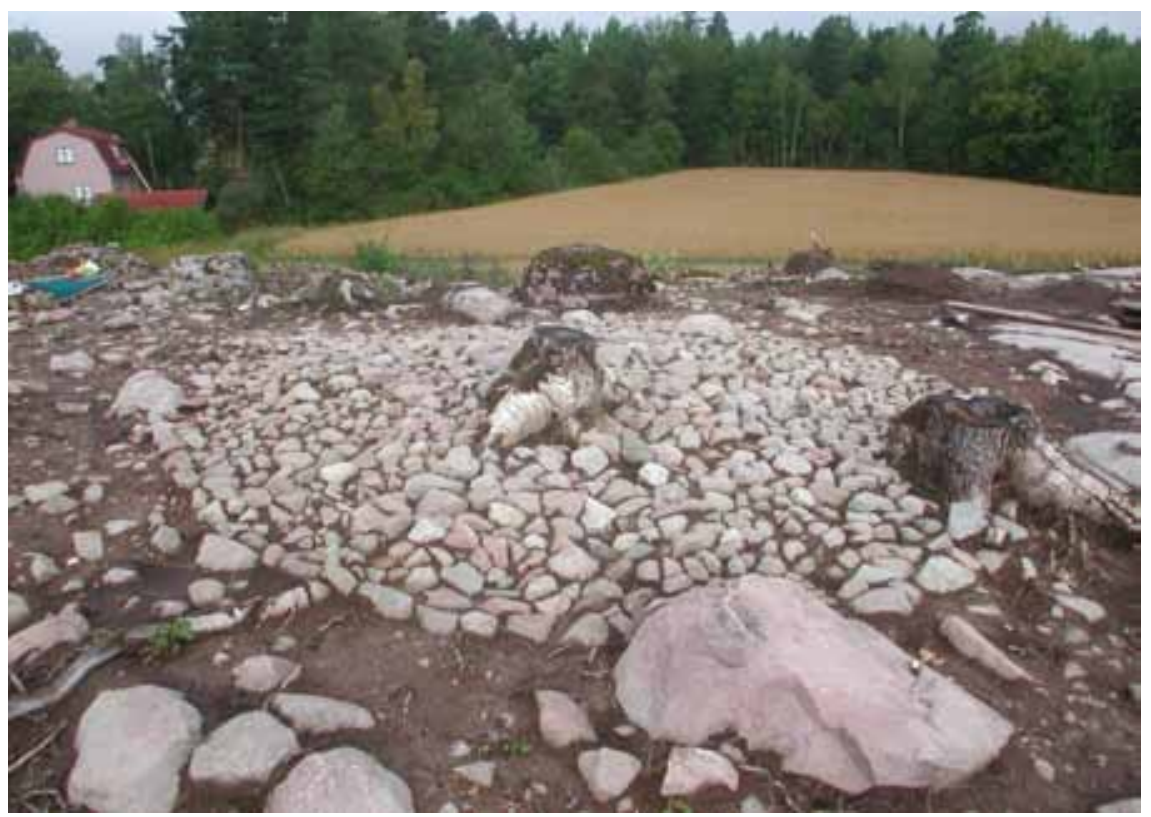


